\title{
BERRY FRUITS AS A SOURCE OF BIOLOGICALLY ACTIVE COMPOUNDS: THE CASE OF LONICERA CAERULEA
}

\author{
Irena Svarcova $^{\mathrm{a} *}$, Jan Heinrich ${ }^{\mathrm{b}}$, Katerina Valentova ${ }^{\mathrm{a}}$
}

\author{
a Department of Medical Chemistry and Biochemistry, Faculty of Medicine and Dentistry, Palacky University, \\ Hnevotinska 3, 77515 Olomouc, Czech Republic \\ b WALMARK a.s., Oldrichovice 44, 73961 Trinec \\ e-mail:irca.svarcova@centrum.cz
}

Received: September 7, 2007; Accepted: October 12, 2007

Key words: Lonicera caerulea/Berries/Polyphenols/Biological activity

Background: Lonicera caerulea L. (blueberry honeysuckle, Caprifoliaceae) is a traditional crop in northern Russia, China, and Japan. Its fruits are little known as edible berries in North America and Europe. This review deals with the botany and chemical composition of $L$. caerulea and the biological activity of its main constituents, focusing on the potential health benefits of the berries.

Methods and Results: PubMed, Science Direct and ISI Web of Knowledge ${ }^{\mathrm{SM}}$ databases were used for this paper. Literature sources include the period 1935-2007.

L. caerulea berries a are rich source of phenolic compounds such as phenolic acids as well as anthocyanins, proanthocyanidins and other flavonoids, which display potential health promoting effects. Chemopreventive, antimicrobial, anti-adherence and antioxidant benefits, among others are described for these compounds.

Conclusions: The potential of $L$. caerulea berries to prevent chronic diseases such as diabetes mellitus, cardiovascular diseases and cancer seems to be related above all to their phenolic content.

\section{INTRODUCTION}

Lonicera caerulea L. (blue berry honeysuckle, Caprifoliaceae) is a traditional crop used in folk medicine in northern Russia, China, and Japan but its fruits are little known as edible berries in North America and Europe ${ }^{1}$. In recent years a large number of studies have investigated the therapeutic effects of various fruits and vegetables in the prevention of a range of diseases and there is increasing interest in herbal medicine products. Berries constitute one of the most important sources of potential health supporting phytochemicals in the human diet ${ }^{2}$. They are a rich source of ascorbic acid and phenolic compounds, particularly phenolic acids, anthocyanins, proanthocyanidins and other flavonoids. These compounds provide the pigmentation of fruits and prove beneficial to human health ${ }^{3,4}$. Their biological activities include: protection against the incidence and mortality rates of cancer ${ }^{5}$, protection against ischemic heart disease mortality ${ }^{6}$ and as well as they have antitumorigenic ${ }^{7}$, antimicrobial ${ }^{8}$, antiinlammatory-allergic ${ }^{9}$ and antimutagenic properties ${ }^{10}$. The aim of this paper was to review the current literature on berry-derived biologically active compounds, with the focus on L. caerulea.

\section{BOTANICAL DESCRIPTION}

The genus Lonicera, which includes almost 180 species of deciduous or evergreen shrubs, belongs to the
Caprifoliaceae family and is native to the Northern Hemisphere (Fig. 1) (ref. ${ }^{1}$ ). The nomenclature of honeysuckles is complicated; a lot of species are sometimes classified as varieties and have many synonyms. Large genetic variation is common among the Lonicera genus. For example 10 common species of $L$. involucrata are only hybrids of one known origin ${ }^{11}$. Many species of Caprifoliaceae family have non-edible fruits and are cultivated only as decorative shrubs or rambling plants ${ }^{12}$, especially for their glorious blooms and ornamental fruits ${ }^{1}$. The fruit colour, which ranges from white or yellow to scarlet or navy blue, is used as an indicator of plant maturity ${ }^{1}$. Honeysuckles are also favoured because of their extreme hardiness to the cold ${ }^{13}$. A few species are used in indigenous medicine as antipyretic, stomachic, diuretic and antidysenteric in India $^{14}$.

L. caerulea L., also known as blue honeysuckle, honeyberry, edible honeysuckle or sweet berry honeysuckle ${ }^{15}$ is native to the northern temperate zone, especially Russia (Kamchatka Peninsula, Siberia), North Eastern Asia, and Japan ${ }^{15,16}$. In Europe, it occurs rarely in the Alps and Scandinavia ${ }^{3}$. L. caerulea is currently commercially produced in Russia and Japan, but this species was unknown as an edible berry in North America until very recently ${ }^{17}$.

Native L. caerulea plants grow from 0.8 to $3.0 \mathrm{~m}$ tall, but under cultivation the shrubs reach $1.0 \mathrm{~m}$ wide to $1.8 \mathrm{~m}$ tall $^{17}$. They do not require special soil type; even wet sandy or loamy soil is suitable, $\mathrm{pH}$ can range from 5 to 7 and the organic proportion can be higher ${ }^{12}$. Plants have strong 


\begin{tabular}{|ll|}
\hline Lonicera caerulea: & \\
Kingdom: & Plantae \\
Subkingdom: & Tracheobionta - Vascular plants \\
Superdivisio: & Spermatophyta - Seed plants \\
Divisio: & Magnoliophyta - Flowering plants \\
Class: & Magnoliopsida - Dicotyledons \\
Subclass: & Asteridae \\
Order: & Dipsacales \\
Family: & Caprifoliaceae \\
Genus: & Lonicera L. - Honeysuckle \\
Species: & Lonicera caerulea L. \\
& - Sweetberry honeysuckle \\
& \\
\hline
\end{tabular}

Fig. 1. Botanical subsumption of Lonicera caerulea L.

tolerance to severe low-temperature conditions. They can survive a temperature of $-46{ }^{\circ} \mathrm{C}$ without damage ${ }^{17,18}$. The freezing tolerance of perennial plants increases in fall and winter to prevent injury under cold conditions. It is known as cold acclimation and seems to be connected with the content and accumulation of specific type of carbohydrates and proteins (see below). The raffinose family of oligosaccharides have been shown to be potential cryoprotectants because of their capacity to modify the freezing behaviour of aqueous solutions ${ }^{18,19}$. Also the presence of galactose-containing oligosaccharides strongly correlates with increases in freezing, as well as desiccation tolerance ${ }^{18}$. Blue honeysuckle shrubs are long-lived and can survive 25 to 30 years $^{12}$.

Blue honeysuckles are not self-pollinating so at least two single plants are required. Fruits become ripe very early in May or June in European conditions. The plants can begin fruiting within one year after planting and after three years almost $500 \mathrm{~g}$ of fruits can be acquired from one plant ${ }^{12}$. Fruit shapes are oval to long and dark navy blue to purple in color ${ }^{15}$ with blue waxy coating according to the genotype ${ }^{12}$. They can grow up to more than $2 \mathrm{~cm}$ long and weigh more than $1.5 \mathrm{~g}^{17}$. Their flavour is similar to that of bilberries or black currants and it can vary from bitter to sweet ${ }^{15}$.

\section{CONSTITUENTS AND THEIR BIOLOGICAL ACTIVITY}

L. caerulea berries and their juice contain saccharides, lipids, proteins, organic acids and polyphenols as major components and also ascorbic acid (45-93 mg $\left.\cdot 100 \mathrm{~g}^{-1}\right)\left(\right.$ ref. $\left.^{15}\right)$, vitamin B, magnesium, phosphorus, calcium and potassium as minor compounds ${ }^{20}$.

\subsection{Saccharides}

L. caerulea fruit contain $7.20 \%$ saccharides. Free saccharides include $3.2 \%$ glucose and $2.9 \%$ fructose, bound saccharides are $0.8 \%$ glucose, $0.2 \%$ galactose and $0.1 \%$ arabinose $^{21}$. Five kinds of saccharides have been identified in L. caerulea shoot apices according to Imanishi et $\mathrm{al}^{18}$. The content of fructose, glucose, saccharose, raffinose and stachyose varies depending on climatic conditions and season. The highest level of sugars has been measured in January, and then the saccharide content decreased to May and after that increased again. According to the literature ${ }^{18}$ the dominant sugar is saccharose with $50-90 \%$ of total saccharides. The content of stachyose and raffinose changes dramatically during the year. While it is negligible from April to November, it increases rapidly from November to March. Fructose and glucose constitute only small proportion of total sugars and their content does not change over the year. Accumulation of raffinose and/or stachyose has strong relationship to the freezing tolerance and desiccation ${ }^{18}$. L. caerulea leaves comprise three glucosides, named caerulosides A, B (Fig. 2) and C. These compounds are formed from secologanin attached through acetal bonds to C-4'and C-6' of the saccharide part of loganin and sweroside, respectively. Caerulosides are the first bis-iridoids, that are composed of two units of iridoids bound by acetal linkages ${ }^{22,23}$.
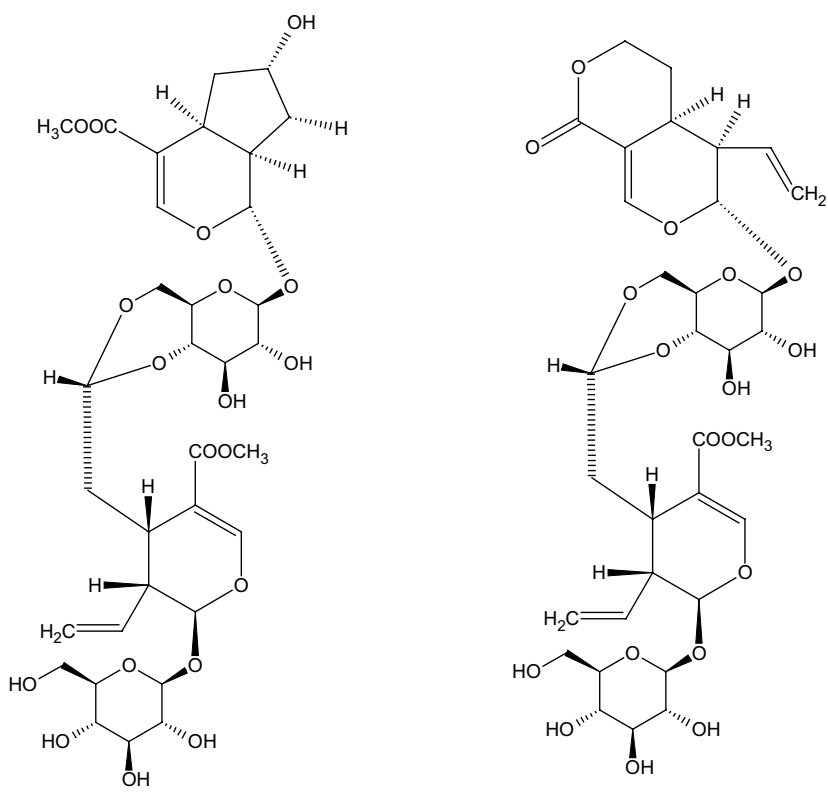

Fig. 2. Caerulosides A and B.

\subsection{Lipids}

Blueberry honeysuckle fruit contain only $1.52 \%$ lipids. The lipid fraction is mainly hydrocarbons, sterols, triacylglycerols and phosphatidylcholine (Table 1a) (ref. ${ }^{21}$ ). The weight of fatty acids is $0.89 \%$ total weight of berries. Main acids include palmitic (38.2\%), oleic (27.6\%), stearic $(14.7 \%)$, myristic $(9.2 \%)$, linolic (5.9\%), palmitoleic $(2.8 \%)$ and lauric acid (1.6\%). The entire weight of the unsaponifiable proportion (sterols, alcohols and hydrocarbons) is $0.46 \%$ of the berries, and includes $\alpha$ amyrin (29.6\%), $\beta$-amyrin (24.7\%), stigmasterol (14.8\%) and ursolic acid (11.5\%) (Table $1 \mathrm{~b})\left(\right.$ ref. $\left.{ }^{24}\right)$. Ursolic acid and its 19-hydroxy derivative pomolic acid were reported to inhibit proliferation and DNA synthesis in HL-60 leukemia cell line at micromolar concentrations ${ }^{25}$. Ursolic acid, $\beta$-amyrin, and glucoside of $\beta$-sitosterol inhibits the growth of HCT 116 human colon cancer cells and PC-12 adrenal pheochromocytoma cells at micromolar concentrations ${ }^{26}$. 
Table 1. Lonicera caerulea berries a) lipid fraction b) unsaponifiable matter.

a)

\begin{tabular}{|l|c|}
\hline \multicolumn{1}{|c|}{ Compounds } & Relative content (\%) \\
\hline Hydrocarbons+sterols & 32.0 \\
\hline Triglycerols & 27.0 \\
\hline Phosphatidyl choline & 21.0 \\
\hline Free fatty acids & 7.0 \\
\hline $\begin{array}{l}\text { Phosphatidic acid, } \\
\text { phosphatidyl serine }+ \\
\text { min. phospholipids }\end{array}$ & 6.0 \\
\hline Digalactosyl diglycerol & 4.0 \\
\hline Phosphatidyl ethanolamine & 3.0 \\
\hline Hydrocarbons+sterols & 3.3 \\
\hline
\end{tabular}

\subsection{Other components}

Fruit content includes $14.62 \%$ dry matter ${ }^{21}$, of which $14.8 \%$ is soluble fiber $^{27}$. Organic acids $(12.2 \%)$ are represented by citric $(3.7 \%)$, malic (18.0\%) and others $(2.4 \%)$ $\left(\right.$ ref. $\left.{ }^{20}\right)$.

\subsection{Phenolic compounds}

Small berries are one of the most important sources of phenolic compounds with potential health promoting effects. L. caerulea contain a huge amount of these compounds. The phenolic content is dependent on the degree of maturity, genetic diversity, preharvest climatic, postharvest storage conditions and processing ${ }^{20}$. We prepared a phenolic fraction from L. caerulea var. kamtschatica $(4 \%$ of fresh fruits) containing $33.5 \%$ of phenolics, including anthocyanins ( $18.5 \%$ ), flavonoids and phenolic acids ${ }^{21}$.

The polyphenols comprise a range of chemical classes of secondary plant metabolites that they all share the ability to act as chain breaking antioxidants ${ }^{28}$. Phenolic compounds are essential for the growth and reproduction of plants and are produced as a response to plant injury by pathogens. At low concentrations they also protect food from oxidative deterioration. At high concentrations they or their oxidation products may interact with proteins, carbohydrates and minerals ${ }^{29}$. The health benefits of polyphenols are usually linked to two properties: (i) inhibition of certain enzymes such as xanthine oxidase, aldose reductase, and (ii) antioxidant activity ${ }^{30}$. Polyphenols can protect other food components such as carotenoids and vitamin $\mathrm{C}$ and also digestive enzymes and gut epithelial cells from oxidation due to free radicals generated in stomach ${ }^{31,32}$.

Little is known about the bioavailability, absorption and metabolism of polyphenols in humans and it is likely that single groups of flavonoids have different pharmacokinetic properties ${ }^{33}$. Phenolics are powerful b)

\begin{tabular}{|l|c|}
\hline \multicolumn{1}{|c|}{ Compounds } & Relative content (\%) \\
\hline$\alpha$-Amyrin & 29.6 \\
\hline$\beta$-Amyrin & 24.7 \\
\hline Stigmasterol & 14.8 \\
\hline Ursolic acid & 11.5 \\
\hline Triterpens & 5.3 \\
\hline Sitosterol & 4.9 \\
\hline Oleanolic acid & 3.3 \\
\hline$\Delta$ 7-Stigmastenol & 3.3 \\
\hline Campesterol & 2.0 \\
\hline Brassicasterol & 0.6 \\
\hline
\end{tabular}

antioxidants in in vitro models, but there is lack of information about whether they can remain a sufficient time in efficient chemical forms in the human body ${ }^{29}$. A large proportion of the ingested polyphenols from berries are not taken up into the circulation and pass through the upper GIT into the large intestine where they may be transformed or broken down by the indigenous microflora ${ }^{34}$. Phenolic compounds are metabolized by deconjugation and reconjugation reactions. They are hydrolyzed to their free aglycones, and then they are conjugated by methylation, sulphation, glucuronidation or their combination. The subsequent metabolic pathway is similar to that of drug metabolism. Since drugs are usually administrated in hundreds of milligrams in one dose while dietary phenolics are presented in much lower concentration, drugs usually saturate these pathways. When food phenolics are administrated at pharmacological doses, they are found in free forms in the blood ${ }^{35}$. Large doses are metabolized primarily in the liver. Small doses may be metabolized in the intestinal mucosa, the liver has a secondary role in their metabolism ${ }^{35}$. Hollman et al. ${ }^{36}$ proposed, based on indirect evidence, that flavonoid glycosides actually may be absorbed intact in the small intestine, using sodium-dependent glucose transporter 1 (SGLT1). On the one hand this postulate has been confirmed ${ }^{37}$. On the other hand it has been demonstrated that the efficiency of such absorption is dramatically suppressed by efflux of at least some flavonoid glycosides by the apical transporter multidrug resistance-associated protein 2 (MRP2) (ref. ${ }^{38}$ ). Some flavonoid glycosides could be hydrolyzed in the small intestine ${ }^{39}$. If the flavonoid glycosides are able to enter the intestinal epithelial cells (enterocytes), which may include shredded cells, they may be hydrolyzed by broadspecific $\beta$-glucosidase $(B S \beta G)\left(\right.$ ref. $\left.{ }^{40}\right)$. For some flavonoid glycosides, lactase phloridzin hydrolase (LPH), located in the brush border of the mammalian small intestine, 
could perform this hydrolysis ${ }^{41}$. It has also been shown, that phenolics, which have rhamnose in their molecule, cannot be absorbed through the small intestine. They are degraded by the action of rhamnosidases produced by the colonic microflora ${ }^{29}$.

\subsubsection{Phenolic acids}

Phenolic acids form approximately one third of the total intake of plant polyphenols in the human $\operatorname{diet}^{42}$. Daily consumption of phenolic acids has been estimated as 25 to $1000 \mathrm{mg}$ (ref. ${ }^{43}$ ). They are present in free and bound forms in plant material. Bound phenolic acids may be linked through ester, ether, acetyl or other bonds ${ }^{42}$. Simple phenolic acids may also be formed by colonic microflora from ingested flavonoids ${ }^{44}$.

Total content of phenolic acids in L. caerulea berries ranges from $2845.8 \pm 141.0$ to $5418.2 \pm 228.0 \mathrm{mg} \cdot \mathrm{kg}^{-1}$, dry weight (DW) $\left(\right.$ ref. $\left.^{45}\right)$. Chlorogenic $(0.42 \%)$, caffeic $(0.14 \%)$ and ferulic acid $(0.10 \%)$ were the most abundant in our phenolic fraction of $L$. caerulea var. kamtschatica berries; the content of protocatechuic, gentisic, rosmarinic, and vanillic acids was $0.08 \%$ in total ${ }^{21}$. Other hydroxycinnamic acid and hydroxybenzoic acid derivatives are mentioned in the literature, especially $m$-coumaric and $p$-coumaric. The amount of hydroxycinnamic acids derivatives is described as comparable to blueberries or blackcurrant ${ }^{46}$. Also dimethoxycinnamic, hydroxycaffeic, gallic, $o$-pyrocatechuic, protocatechuic, salicylic, $p$-hydroxyphenylacetic and $p$-hydroxyphenyllactic acid are reported $^{45}$.

Free phenolic acids stand for only a minor portion of phenolic acids. Their amounts ranged from 1.7 to 4.2 $\%$ for all berries. Caffeic, ferulic and $p$-coumaric acids predominate. Free phenolic acids levels do not exceed taste threshold and they do not influence the taste of the berries $^{45}$.

Bound phenolic acids are present in ester (69.7\%) form. $L$. caerulea again contains $m$-coumaric acids as the dominant acid. Also caffeic, ferulic, gallic, $p$-hydroxyphenylacetic, $p$-hydroxyphenyllactic and vanillic acid occur in minor amounts. Phenolic acids bound by glycosidic linkages constitute $28.6 \%$. The majority are represented by hydroxycinnamic acid derivatives $(61.1 \%)$, especially $m$-coumaric. The content of ferulic, gentisic, protocatechuic and vanillic acids does not reach $50 \mathrm{mg} \cdot \mathrm{kg}^{-1}$, DW (ref. ${ }^{45}$ ).

Chlorogenic acid is formed by the esterification of caffeic acid with quinic acid. It can be also degraded to caffeic and quinic acid by esterases produced by the colonic microflora ${ }^{47}$. Caffeic acid is known as an antioxidant both in vitro and in vivo ${ }^{48}$. While both caffeic and chlorogenic acid have been reported to be absorbed in humans ${ }^{49}$, caffeic acid absorption is nevertheless hampered when it is esterified with quinic acid. Caffeic acid is still listed under older Hazard Data sheets as a potential carcinogen because of two early experiments on rats and mice. More recent data show that bacteria in the rat's guts may alter the formation of caffeic acid metabolites. There have been no known adverse effect of caffeic acid in humans ${ }^{50,51}$. Ferulic acid could be absorbed by passive diffusion or by facilitated transport that appears not be saturated even at a luminal concentration of $50 \mu \mathrm{mol} / 1\left(\right.$ ref. $^{52}$ ). The absorption of ferulic acid and also free cinnamic acid are controlled by the $\mathrm{Na}^{+} /$dependent carrier-mediated transport process in rat jejunal segments ${ }^{53}$. Some food products also contain oxidatively coupled product of the ferulic acid, the diferulic acid ${ }^{54}$. Coumaric acid is a hydroxy derivative of cinnamic acid. There are three isomers, $o$-coumaric, $m$-coumaric and $p$-coumaric acid, that differ by the position of the hydroxy substitution of the phenyl group. $p$-Coumaric acid is the most abundant isomer in nature, has antioxidant properties ${ }^{55}$ and is believed to reduce the risk of stomach cancer ${ }^{56}$.

\subsubsection{Flavonoids}

Flavonoids are polyphenolic compounds, whose structure is formed by the diphenyl propane skeleton $\left(\mathrm{C}_{6}-\mathrm{C}_{3}-\mathrm{C}_{6}\right)$. The differences within each group flow from variation in numbering and order of the hydroxyl groups, as well as the nature and extent of alkylation and glycosylation of these groups. The degree of hydroxylation is a determinant for their tendency to degradation in the colon and products formed by colonic microflora. The absence of hydroxyl group in the molecule prevents the degradation of the ring structure; the degree of hydroxylation magnifies the tendency to degradation. The absence of the methyl group causes a decrease in the tendency to degradation ${ }^{57}$. Food flavonoids are usually glycosylated mostly with glucose or rhamnose, but galactose, arabinose, xylose; glucuronic acid and other sugars can also be found. The number of sugar molecules can be one, two or three in different possible positions of the ring substitution. The glycosylation influences chemical, physical and biological properties of these compounds ${ }^{35}$.

The extent of absorption and bioavailability of drugs has long been known to be affected by membrane transporters, mainly efflux transporters, in addition to metabolism. The traditional efflux transporter for drugs, e.g. P-glycoprotein, does not seem to be involved in the transport of flavonoids. Other transporters have been found to play a role, e.g. the absorptive transporter SGLT1 (ref. ${ }^{38}$ ), the absorptive monocarboxylate transporter (MCT), MRP2, but probably also other MRP isoforms, for glucuronide and sulphate conjugates ${ }^{38,58}$.

The metabolism of flavonoids was initially described to be mediated by cytochrome P450 (CYP) enzymes ${ }^{59}$ in liver microsomes from induced rats and from humans, but it has never been shown to be important in vivo or in intact cells, where conjugative metabolism may be expected to compete with oxidation ${ }^{60}$. Glucuronic acid conjugates of flavonoids have been well-documented with respect to both the molecular site of glucuronidation and the UD P-glucuronyltransferase (UGT) isoforms involved ${ }^{61}$. One of the tea flavonoids, epicatechin gallate (ECG), showed only sulphate conjugation ${ }^{62}$. Other metabolic pathways include O-methylation by soluble catechol-O-methyltransferase (COMT) $\left(\right.$ ref. $\left.^{63}\right)$ or by bacterial enzymes. Bacteria 
from faecal flora may be responsible for the hydrolysis of flavonoids glycosides as well as flavonoid glucuronides and sulphates. The reaction proceeds via degradation of the flavonoid backbone into numerous phenolic and carboxylic acid products ${ }^{64}$, as well as carbon dioxide ${ }^{65}$. Many of these products are absorbed and can be detected in human urine ${ }^{64}$. Other types of metabolites are those resulting from oxidation by reactive oxygen species (ROS $)^{66}$. Covalent binding of oxidized quercetin to DNA and cellular protein has been demonstrated in human cells ${ }^{67}$.

\subsubsection{Flavonols, flavons and flavan-3-ols}

Flavonols (e.g. quercetin) have a similar C-ring structure with a double bond in the 2-3 position as flavones (e.g. apigenin). Flavones lack a hydroxyl group at the 3-position. Flavan-3-ols (e.g. epicatechin) lack a double bond in the $2-3$ position. Quercetin $(0.1 \%$ of the phenolic fraction), its 3-glycoside $(0.06 \%)$ and 3-rutinoside $(0.75 \%)$ and minor quantities of epicatechin and apigenin were found in our L. caerulea var. kamtschatica phenolic fraction ${ }^{21}$.

Quercetin is one of the most extensively studied flavonoids apropos its anticancer activity because of its prevalence among fruits and vegetables (Fig. 3) (ref. ${ }^{68}$ ). Quercetin glucosides are resistant to hydrolysis by $\mathrm{HCl}$ in stomach ${ }^{69}$ and the absorption occurs in the small intestine into enterocytes probably via active transport ${ }^{70,71}$. They can be methylated into isorhamnetin immediately after absorption in the human body. Quercetin rutinosides are

a)<smiles>O=c1c(O)c(-c2ccc(O)c(O)c2)oc2cc(O)cc(O)c12</smiles>

b)<smiles>O=c1cc(-c2ccc(O)cc2)oc2cc(O)cc(O)c12</smiles>

c)<smiles>Oc1cc(O)c2c(c1)O[C@H](c1ccc(O)c(O)c1)[C@H](O)C2</smiles>

Fig. 3. Chemical structures of a) quercetin; b) apigenin; c) epicatechin. absorbed from the colon following the deglycosylation ${ }^{71}$. After intravenous dose, quercetin can be detected in urine, in particular after hydrolysis with $\beta$-glucuronidase/aryl sulphatase ${ }^{72}$. The main route of quercetin excretion is as carbon dioxide, 23 - $81 \%$ of the dose, measured by trapping exhaled air $^{73}$. Apigenin is a nontoxic dietary flavonoid that has been shown to have anti-tumour and anti-inflammatory activities (Fig. 3). Apigenin can block the formation of uric acid leading to beneficial effects in gout ${ }^{74}$. Catechin and epicatechin are epimers, with (-)-epicatechin and $(+)$-catechin being the most common optical isomers found in nature (Fig. 3) ( ref. $^{75}$ ). Epicatechin can reduce the risk of four of the major health problems: stroke, heart failure, cancer and diabetes ${ }^{76}$. Acylated flavonoids, such as epicatechin are reported to be absorbed without deconjugation and hydrolysis ${ }^{77}$.

\subsubsection{Anthocyanins}

Anthocyanins are secondary plant metabolites, derivatives of 2-phenylbenzopyrylium, generally found in glycosidic forms ${ }^{78-80}$. The aglycones (anthocyanidins) are rarely found in fresh plants. They occur as 3-glycosides and 3,5diglycosides linked with glucose, galactose, rhamnose or arabinose $^{78}$. Anthocyanins represent the most important group of water-soluble pigments, responsible for the blue, purple and red colour of many plant tissues due to their ability to associate into complexes characterized by higher absorbance of light lengths, co-pigmentation and formation of complexes with metals. In aqueous solution, anthocyanins exist in a number of different molecular forms that are in dynamic equilibrium depending mostly on $\mathrm{pH}$ (Fig. 4). The red flavylium cation is the most abundant molecular form at $\mathrm{pH}<2$. As the $\mathrm{pH}$ increases, there is rapid loss of a proton to generate the blue quinonoidal structure. At the same time, much slower hydration of the flavylium cation occurs to yield the colourless hemiketal form that further tautomerises to generate the chalcone form ${ }^{81}$. The positively-charged oxonium anthocyanin form may not be affected by MRP2 efflux, which seriously limits the absorption of other flavonoid glycosides ${ }^{38}$. Anthocyanins seem to be able to be absorbed intact as glycosides ${ }^{82}$. However, the proportion of anthocyanins absorbed and excreted in the urine appears to be quite small, perhaps much less than $0.1 \%$ of the intake ${ }^{83}$. The clearance of anthocyanins from the circulation is rapid; very little is generally detected in the plasma $6 \mathrm{~h}$ after administration $^{82}$. Some anthocyanins can be metabolized to colourless forms, oxidized, or degraded into other compounds. Researchers have also found that no glycoside hydrolysis takes place during digestion ${ }^{84}$. The absorption of anthocyanins without removal of glycoside has also been demonstrated ${ }^{85}$.

Anthocyanins and proanthocyanidins have antibacterial properties as well as the ability to inhibit adhesion of bacteria to mucosal membrane of urinary tract ${ }^{86}$. Anthocyanins also act as anti-inflammatory and anti-mutagenic agents and provide cardioprotection by maintaining vascular permeability ${ }^{4}$. The ability to regulate the perme- 


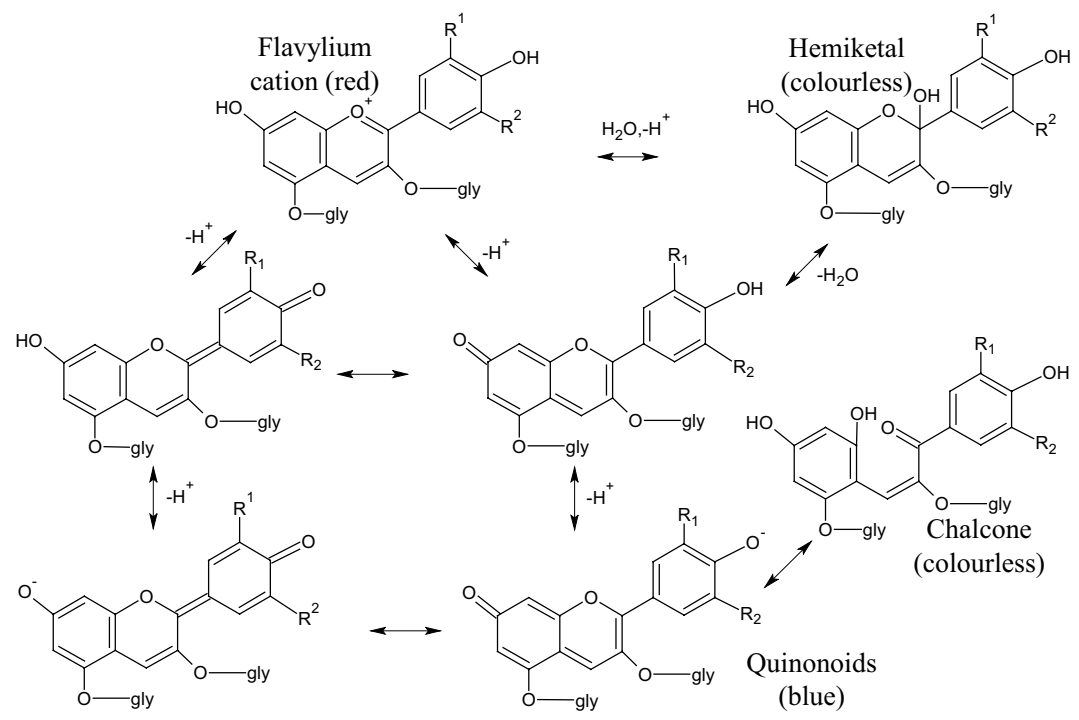

Fig. 4. Various anthocyanin forms existing in aqueous solutions depending on $\mathrm{pH}(\mathrm{gly}=$ glycoside).

ability of capillary vessels has become the basis for their definition as vitamin $\mathrm{P}$. They show protection against hepatitis $\mathrm{A}$ and $\mathrm{B}$ and also against paracetamol hepatotoxicity $^{87}$. Berry extracts rich in anthocyanins have been linked to protective effects including the modulation of age-related neurological dysfunctions and improved resistance of red blood cells against oxidative stress in vitro ${ }^{88}$.

Anthocyanins are very good antioxidants due to the presence of hydroxyl groups in position 3 of the $\mathrm{C}$ ring, which can chelate metal ions ( $\mathrm{Fe}, \mathrm{Cu})$, and $3^{\prime}$ and $4^{\prime}$ of the $\mathrm{B}$ ring. Antioxidant activity is also increased by acylation of sugar residues with aromatic hydroxy acids ${ }^{89}$. These compounds have higher antioxidative activities than vita$\min \mathrm{E}$, ascorbic acid or $\beta$-carotene ${ }^{79}$.

The major anthocyanins in $L$. caerulea fruit are the glucosides and rutinosides of cyanidin, peonidin, dephinidin and pelargonidin ${ }^{21}$ (Fig. 5). Quantities of these compounds vary depending on a number of the factors ${ }^{46}$. Table 2 shows a comparison of $L$. caerulea phenolic fraction anthocyanin content with those of Vaccinium macrocarpon $^{90}$ and Vitis vinifera ${ }^{91}$.<smiles>[R]c1cc(-c2[o+]c3cc(O)cc(O)c3cc2O)cc([R])c1[R]</smiles>

Fig. 5. Structures of main anthocyanidins.
Cyanidin is the most common anthocyanidin, with a 3', 4'-dihydroxylation of the B ring, present in $90 \%$ of fruits $^{92}$. Wu et al. ${ }^{83}$ detected the methylated form of anthocyanins in human urine after consumption of elderberries and blueberries. The cyanidin glycosides tend to have higher antioxidant capacity than peonidin or malvidin glycosides likely due to the free hydroxyl groups on the $3^{\prime}$ and 4 ' positions of cyanidin ${ }^{93}$. The key difference compared to other flavonoid glucosides, is that cyanidin3-glucoside appears to be absorbed after oral ingestion, although to a limited extent ${ }^{38}$. Cyanidin-3-rutinoside from sweet cherry exhibited cyclooxygenase I and II inhibitory activities $^{94}$. It showed potential in the treatment of diabetes, obesity, hyperlipidemia ${ }^{95}$ and $\mathrm{B}$ and $\mathrm{C}$ type viral hepatitis ${ }^{96}$. Delphinidin may preserve endothelium integrity and protect against endothelial cell apoptosis ${ }^{97}$. Delphinidin, malvidin and petunidin are metabolized in the liver through the catechol-O-methyltransferase reaction in the $3{ }^{1}$ position $^{83}$. Pelargonidin itself displays an orange red color. Pelargonidin-3-monoglucoside, isolated from frozen strawberries, protected the amino acid tyrosine from the highly reactive oxidant peroxynitrite, inhibited the growth

\begin{tabular}{|l|c|c|c|}
\hline Name & $\mathrm{R}^{1}$ & $\mathrm{R}^{2}$ & $\mathrm{R}^{3}$ \\
\hline Cyanidin & $\mathrm{OH}$ & $\mathrm{OH}$ & $\mathrm{H}$ \\
\hline Delphinidin & $\mathrm{OH}$ & $\mathrm{OH}$ & $\mathrm{OH}$ \\
\hline Pelargonidin & $\mathrm{H}$ & $\mathrm{OH}$ & $\mathrm{H}$ \\
\hline Peonidin & $\mathrm{OCH}_{3}$ & $\mathrm{OH}$ & $\mathrm{H}$ \\
\hline Petunidin & $\mathrm{OCH}_{3}$ & $\mathrm{OH}$ & $\mathrm{OH}$ \\
\hline Malvidin & $\mathrm{OCH}_{3}$ & $\mathrm{OH}$ & $\mathrm{OCH}_{3}$ \\
\hline
\end{tabular}


Table 2. Content of anthocyanins in Lonicera caerulea, Vaccinium macrocarpon and Vitis vinifera extracts.

\begin{tabular}{|c|c|c|c|}
\hline \multirow[t]{2}{*}{ Compounds } & \multicolumn{3}{|c|}{ Relative content (\% w/w) } \\
\hline & L. caerulea $^{21}$ & V. macrocarpon ${ }^{90}$ & V. vinifera $^{91}$ \\
\hline Cyanidin-3-arabinoside & - & 5.5 & - \\
\hline Cyanidin-3-galactoside & - & 7.1 & - \\
\hline Cyanidin-3-glucoside & 60.0 & 12.3 & 7.0 \\
\hline Cyanidin-3(6'-acetyl)-glucoside & - & - & 1.8 \\
\hline Cyanidin-3,5-diglucoside & 9.9 & - & - \\
\hline Cyanidin-3-pentoside & - & 2.9 & - \\
\hline Cyanidin-3-rutinoside & 7.3 & - & - \\
\hline Delphinidin & - & 1.8 & - \\
\hline Delphinidin-3-glucoside & 1.2 & - & 3.7 \\
\hline Delphinidin-3-rutinoside & 2.0 & - & \\
\hline Pelargonidin-3-glucoside & 3.3 & - & - \\
\hline Pelargonidin-3,5-diglucoside & 0.6 & - & - \\
\hline Pelargonidin-3-rutinoside & 0.1 & - & - \\
\hline Peonidin-3-arabinoside & - & 5.7 & - \\
\hline Peonidin-3-galactoside & - & 10.2 & - \\
\hline Peonidin-3,5-digalactoside & - & 24.1 & - \\
\hline Peonidin-3-glucoside & 5.8 & 60.7 & 18.7 \\
\hline Peonidin-3,5-diglucoside & 8.1 & - & \\
\hline Peonidin-3(6'-coumaroyl)-diglucoside & - & - & 1.2 \\
\hline Peonidin-3-rutinoside & 0.5 & - & - \\
\hline Petunidin-3-glucoside & - & - & 10.7 \\
\hline Malvidin-3-glucoside & - & - & 64.6 \\
\hline Malvidin-3(6'-acetyl)-glucoside & - & - & 1.0 \\
\hline Malvidin-3(6'-caffeoyl)-glucoside & - & - & 1.8 \\
\hline Malvidin-3(6'-coumaroyl)-glucoside & - & - & 2.5 \\
\hline Total anthocyanins & 100 & 100 & 100 \\
\hline
\end{tabular}

of Escherichia coli and Staphylococcus aureus, and exerted both a stimulatory and inhibitory effect on Lactobacillus casei culture. The stimulation may be due to a decrease in the oxidation-reduction potential of the media affected by the pigment, and/or the ability of the organism to split the $\beta$-glycosyl bond and use the glucose moiety ${ }^{98}$. Peonidin has been patented for use as food colouring agent ${ }^{99}$.

\subsubsection{Proanthocyanidins}

Proanthocyanidins (condensed tannins) are oligomeric and polymeric end products of the flavonoid biosynthetic pathway and are metabolized to anthocyanidins ${ }^{79}$. They can be considered as the fifth class of plant biopolymers besides polynucleotides, proteins, lignins and polysaccharides. As a class, proanthocyanidins can be complex in structure and composition, featuring various flavan-3-ols (most commonly catechin, epicatechin, and galloylated catechins) linked together in different ways. Berry proanthocyanidins are primarily dimers, trimers and other oligomers $^{100}$. These molecules may contain two types of linkages between epicatechin units. The B-type $(4 \beta \rightarrow 8)$ is widely found in apples and grapes and A-type $(4 \beta \rightarrow 8$ and 


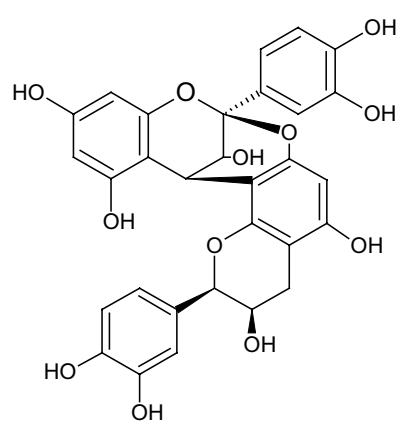<smiles>[Z20]C1([Z20])Cc2c(O)cc(O)c(C3c4c(O)cc(O)cc4O[C@H](c4ccc(O)c(O)c4)[C@H]3c3ccc(O)c(O)c3)c2O[C@H]1c1ccc(O)c(O)c1</smiles>

Fig. 6. Chemical structures of proanthocyanidin A and B type.

$2 \beta \rightarrow \mathrm{O} \rightarrow 7$ ) found in cranberries can inhibit adherence of uropathogenic P-fimbriated Escherichia coli (Fig. 6) (ref. ${ }^{101,102}$ ). The stereochemistry of the linkage at $\mathrm{C} 4$ may be $\alpha$ or $\beta^{103}$. The major function of proanthocyanidins in plants is to provide protection against microbial pathogens, insect pests and larger herbivores. Their deposition in the endothelial layer of the seed coat appear to be an example of a pre-formed protective barrier ${ }^{104}$. Salmonella, Staphylococcus, Helicobacter and Bacillus are the most sensitive bacteria to the berry phenolics. In addition, the growth of Escherichia, Clostridium and Campylobacter species but not Lactobacillus and Listeria species are inhibited $^{105}$. The main mechanisms of action are destabilization of cytoplasmic membrane, permeabilization of plasma membrane, inhibition of extracellular microbial enzymes, direct actions on microbial metabolism and deprivation of the substrates required for microbial growth ${ }^{106}$.

\section{TRADITIONAL USE AND PUTATIVE HEALTH BENEFITS}

L. caerulea berries have long been harvested from wild plants in regions of Russia, China and Japan where superior edible forms are native. Recently, research in Russia and Japan has resulted in cultivars being selected for commercial production because of its very early maturity, unique flavour and health benefits that have long been acknowledged in Russia ${ }^{16}$. Recent research has supported some of the folkloric claims for the therapeutic uses of blue honeysuckle berries in atherosclerosis, hypertension, gastrointestinal disorders and bacterial infection. The main beneficial effect is due to the presence of vitamin C and high levels of polyphenolics ${ }^{16,107-110}$.
L. caerulea phenolics, as secondary plant metabolites, have been shown to provide defence against oxidative stress from endogenous ROS and free radicals ${ }^{111}$. Tumor inhibition by the berries is likely to involve synergic activities between its phytochemicals, including flavonols (quercetin), proanthocyanidins and others and to be primarily based on reducing oxidation of lipoproteins, improving antioxidant status and lipid levels and mitigating the effect of oxidative stress and inflammation on the vascular system ${ }^{112}$. Phenolics protect cardiomyocytes after ischemic episodes by inhibition of free radical formation in the process of reperfusion ${ }^{113}$. These compounds are able to reduce nitric oxide synthase activity and nitric oxide (NO) level ${ }^{114}$. They inhibit the cyclooxygenase activity, adhesion and reaction of leukocytes with endothelial cells, degranulation of mast cells and decrease in the level of interleukin (IL)-2, interferon (INF) $-\gamma$ and tumor necrosis factor (TNF)- $\alpha$ $\left(\right.$ ref. $\left.{ }^{115}\right)$. Polyphenolics have been regarded as a potential novel, safe and nontoxic strategy for the modulation of inflammation dependent on the nuclear factor (NF)-kB pathway ${ }^{27}$. An extract of $L$. caerulea showed significant anti-inflammatory effects on endotoxin-induced uveitis in rat. The possible mechanisms for this effect may depend especially on its ability to inhibit activation of NF-kB and the subsequent production of proinflammatory mediators such as TNF- $\alpha$, prostaglandin (PG)- $\mathrm{E}_{2}$ and NO (ref. ${ }^{27}$ ).

Berry anthocyanins act as novel cardioprotectants by maintaining vascular permeability, reducing inflammatory responses and platelet aggregation, and offer superior vascular protection compared to other cardioprotective drugs ${ }^{116,117}$. Bioactive compounds from $L$. caerulea have been also demonstrated in in vitro models to inhibit the oxidation of lipoproteins. A recent study of ours showed inhibition of copper-induced lipoprotein oxidation by a phenolic fraction of $L$. caerulea var. kamtschatica ${ }^{118}$. Reduction of atherosclerotic plaques by polyphenolics has been found in animal models; reduction of carcinogenesis was observed in vitro. Epicatechin ${ }^{76}$ and anthocyanins, especially delphinidin, may preserve endothelium integrity whose damage can lead to the development of atherosclerosis and also cancer ${ }^{97}$. Some $L$. caerulea compounds can block mutagenesis by chemical carcinogens and endogenous mutagens and have been shown to modify the process of uncontrolled cell proliferation and apoptosis in vitro ${ }^{119}$. These phytochemicals may exert their anticarcinogenic effect by modulating the enzyme systems that metabolize carcinogens or procarcinogens to genotoxins. For example CYP activity can be induced or inhibited by flavonoids. Ellagic acid inhibits mutagenesis and carcinogenesis by acting on both CYP xenobiotic metabolism and several phase 2 detoxifying enzymes ${ }^{120}$. Berry extracts can protect against carcinogenesis also in animal models ${ }^{121}$. Numerous reports shows quercetin ability to inhibit proliferation of cancer cell lines in vitro, including breast, colon, pancreas cancer, and leukemia ${ }^{122}$. Its mechanism of action includes induction of apoptosis ${ }^{123}$, inhibition of epidermal growth factor receptor expression and associated tyrosine kinase activity ${ }^{122}$, reduced expression of Ras protein in colon cancer cells and primary colorectal tumors $^{124}$, increased expression of endogenous inhibitors 
of matrix metalloproteinases ${ }^{125}$ and phytoestrogenic activity involving interaction with the estrogen $\alpha$ - and $\beta$-receptors of human breast cancer MCF-7 cells ${ }^{68}$. Cyanidin and its 3-glycoside reduce oxidant-induced DNA strand breakage in normal human lymphocytes ex vivo and are as potent chemoprotectants as the flavonols, quercetin and myricetin. Cyanidin-3-rutinoside and cyanidin-3-glucoside suppress cancer cell metastasis by inhibiting the motility adhesiveness and invasiveness of metastatic human lung cancer cell lines A579 (ref. ${ }^{126}$ ). Cyanidin and a mixture of several of its glycosides dose-dependently inhibited HCT 116 and HT 29 colon cancer cell growth ${ }^{127}$. Delphinidin, malvidin and petunidin also inhibited proliferation of cancer cells derived from various tissues including colon, breast, blood and lung at high micromolar concentrations $^{128}$. Peonidin has shown potent inhibitory and pro-apoptotic effects on cancer cells in vitro, notably human metastatic breast cancer cells ${ }^{99}$. $p$-Coumaric acid is believed to reduce the risk of stomach cancer by reducing the formation of carcinogenic nitrosamines ${ }^{56}$. Also caffeic acid and epicatechin have been shown to act as an inhibitor of carcinogenesis ${ }^{48,76}$. Wild and cultivated berry proanthocyanidin fractions demonstrated antiproliferative effects on two models of prostate cancer: an androgen-sensitive (LNCaP) and more aggressive androgen-insensitive cell line (DU145) $\left(\right.$ ref. $^{129}$ ).

Several berry derivatives have also potent anti-angiogenesis properties in vitro by altering vascular endothelial growth factor (VEGF) expression and invasiveness. Berry extracts can inhibit hydrogen peroxide and TNF- $\alpha$ induced VEGF expression in these cells and also inhibit angiogenesis in animals ${ }^{130}$. For example apigenin inhibits expression of VEGF in human ovarian cancer cells ${ }^{74}$.

Polyphenolic fractions from plants can display insulin-like effects by reducing blood glucose levels after food intake $^{131}$. The main effect may be due to inhibition of starch degradation within the gastrointestinal tract (GIT) by inhibiting $\alpha$-glucosidase/maltase activity ${ }^{132}$. It has been shown, that anthocyanins, especially diacylated forms owing to intestinal $\mathrm{pH}$, inhibit $\alpha$-glucosidase activity and can reduce blood glucose levels after starch-rich meals, a proven clinical treatment for controlling diabetes mellitus type II (ref. ${ }^{132,133}$ ). Anthocyanins can directly induce insulin secretion from pancreatic cells in ex vivo models, but this effect may be disregarded because of its low serum bioavailability ${ }^{31,134}$. Cyanidin-3-glucoside, quercetin, ferulic acid, peonidin-3-glucoside and tocopherol, in this order, showed significant inhibitory activity against aldose reductase activity ${ }^{135}$. Cyanidin-3-rutinoside inhibited $\alpha$-glucosidase from baker's yeast in a dose-dependent manner ${ }^{136}$. It can lead to a reduction in glucose absorption and therefore the rise of postprandial hyperglycemia can be attenuated ${ }^{94}$. Berry anthocyanins appear to benefit vision in several ways in diabetes, including improving night vision by enhanced generation of retinal pigment, increasing circulation within the capillaries of the retina, decreasing macular degeneration and diabetic retinopathy, and improving or preventing glaucoma and cataracts ${ }^{137}$.

A range of berry polyphenols can inhibit protease activities at levels which may affect protein digestion in the
GIT. Soluble proanthocyanidins can inhibit pancreatic and gastric lipase activity and therefore would be a target in the treatment of obesity ${ }^{133}$. Berries have also been shown to reverse age-related and oxidative stress-induced decline in brain function in rats ${ }^{138}$.

\section{CONCLUSION}

Lonicera caerulea berries contain $7.20 \%$ saccharides, $1.52 \%$ lipids, $14.62 \%$ dry matter, $12.2 \%$ organic acids and $4 \%$ phenolics, containing $33.5 \%$ of phenolics, including anthocyanins (18.5\%), flavonoids and phenolic acids. The major anthocyanins in L. caerulea fruit are glucosides and rutinosides of cyanidin, peonidin, dephinidin and pelargonidin. These berries seem to be prospective sources of health supporting phytochemicals that exhibit beneficial activities such as anti-adherence, antioxidant and chemoprotective, thus they may provide protection against a number of chronic conditions, e.g. cancer, diabetes mellitus, tumor growth or cardiovascular diseases. These plants can be cultivated in European climatic conditions and therefore are a suitable source of economically accessible nutraceutical preparations.

\section{ACKNOWLEDGEMENTS}

This study was supported by grants MSM 6198959216 and FT-TA3/024 that are gratefully acknowledged.

\section{REFERENCES}

1. Huxley A. The New Royal Horticultural Society Dictionary of Gardening. 1992; 3:790.

2. Fukumoto LR, Mazza G. Assessing antioxidant and prooxidant activities of phenolic compounds. J. Agric. Food Chem. 2000; 48:3597-3604.

3. Hummer KE. Blue honeysuckle: A new berry crop for North America. J. Am. Pomol. Soc. 2006; 60:3-8.

4. Bagchi D, Sen CK, Bagchi M, Atalay M. Anti-angiogenic, antioxidant, and anti-carcinogenic properties of a novel anthocyanin-rich berry extract formula. Biochemistry (Moscow) 2004; 69:75.

5. Doll R. An overview of the epidemiologic evidence linking diet and cancer. Proc. Nutr. Soc. 1990; 49:119-131.

6. Armstrong BK, Mann JI, Adelstein AM, Eskin F. Commodity consumption and ischemic heart-disease mortality, with special reference to dietary practices. J.Chron. Dis. 1975; 28:455-469.

7. Bingham SA. Mechanisms and experimental and epidemiologic evidence relating dietary fiber (nonstarch polysaccharides) and starch to protection against large-bowel cancer. Proc. Nutr. Soc. 1990; 49:153-171.

8. Puupponen-Pimia R, Nohynek L, Meier C, Kahkonen M, Heinonen M, Hopia A, et al. Antimicrobial properties of phenolic compounds from berries. J. Appl. Microb. 2001; 90:494-507.

9. Middleton E, Kandaswami C. Effects of flavonoids on immune and inflammatory cell functions. Biochem. Pharmacol. 1992; 43:11671179.

10. Edenharder R, Vonpetersdorff I, Rauscher R. Antimutagenic effects of flavonoids, chalcones and structurally related-compounds on the activity of 2-amino-3-methylimidazo[4,5-F]quinoline (Iq) and other heterocyclic amine mutagens from cooked food. Mut. Res. 1993; 287:261-274 
11. Erstad JLF. Annual shoot growth in different populations of Lonicera involucrata collected in North America and grown in Norway. Euphytica 1991; 53:165-171.

12. Plekhanova MN. Blue Honeysuckle: a new berry from Russia. Pomona 1996; 29:46 - 48.

13. Herman DE, Davidson, C.G. Evaluation of Lonicera taxa for honeysuckle aphid susceptibility, winter hardiness and use. J. Environ. Hort. 1997; 15:177 - 182.

14. Kirtikar KR, Basu, B.D. Indian Medicinal Plants. Delphi 6: Taj Offset Press; 1935.

15. Thompson M, Chaovanalikit, A. Preliminary observations on adaptation and nutraceutical values of blue honeysuckle (Lonicera caerulea) in Oregon, USA. Acta Hortic. 2003; 626:65-72.

16. Bors B. Blue Honeysuckle. [cited 17. 2. 2007]. Available from: http://www.usask.ca/agriculture/plantsci/dom_fruit/articles/blue honeysuckle.pdf

17. Plekhanova MN. Blue honeysuckle (Lonicera caerulea L.) - a new comercial berry crop for temperate climate: genetic resources and breeding. Acta Hortic. 2000; 538:159 - 164.

18. Imanishi HT, Suzuki T, Masuda K, Harada T. Accumulation of raffinose and stachyose in shoot apices of Lonicera caerulea $L$. during cold acclimation. Sci. Hort. 1998; 72:255-263.

19. Goldstein G, Nobel PS. Water relations and low-temperature acclimation for cactus species varying in freezing tolerance. Plant Physiology 1994; 104:675-681.

20. Shahidi F, Naczk, M. Phenolics in Food and Nutraceuticals. Boca Raton: CRC Press; 2003.

21. Svarcova I, Heinrich, J., Bednar, P., Kren, V., Cvak, L., Ulrichova, J., Simanek, V., Valentova, K. Main components and radical scavenging activity of Lonicera caerulea L. var. kamtschatica berries. 50 Years of the Phytochemical Society of Europe. 11. -14. 4. 2007; Cambridge, UK, p. 94-95

22. Machida K, Asano J, Kikuchi M. Analysis of the components of Lonicera species. 3. Caeruleoside-A and caeruleoside-B, bis-iridoid glucosides from Lonicera caerulea. Phytochemistry 1995; 39:111114.

23. Machida K, Kikuchi M. An iridoid glucoside from Lonicera caeruee Phytochemistry 1995; 40:603-604.

24. Ulrichová J, Bednar P, Kren V, Valentova K, Heinrich J, Svarcova I, Svobodova A, Reichenbach R, Cvak L, Simanek V. Characterization of Lonicera caerulea anthocyanines and phenolics by $\mu \mathrm{LC}-\mathrm{MS}^{2}$ and assessment of their biological activities. 3rd International Conference on Polyphenols and Health. 25.-28.11. 2007; Kyoto, Japan, p.

25. Wang MF, Li JG, Rangarajan M, Shao Y, LaVoie EJ, Huang TC, et al. Antioxidative phenolic compounds from sage (Salvia officinalis). J. Agric. Food Chem. 1998; 46:4869-4873.

26. Ono M, Koto M, Komatsu H, Igoshi K, Kobayashi H, Ito Y, et al. Cytotoxic triterpenes and sterol from the fruit of rabbiteye blueberry (Vaccinium ashei). Food Sci. Technol. Res. 2004; 10:56-59.

27. Jin XH, Ohgami K, Shiratori K, Suzuki Y, Koyama Y, Yoshida K, et al. Effects of blue honeysuckle (Lonicera caerulea L.) extract on lipopolysaccharide-induced inflammation in vitro and in vivo. Exp. Eye Res. 2006; 82:860-867.

28. Manach C, Williamson G, Morand C, Scalbert A, Remesy C. Bioavailability and bioefficacy of polyphenols in humans. I. Review of 97 bioavailability studies. Am. J. Clin. Nutr. 2005; 81:230S$242 \mathrm{~S}$.

29. Karakaya S. Bioavailability of phenolic compounds. Crit. Rev. Food Sci. Nutr. 2004; 44:453-464.

30. Cotelle N. Role of flavonoids in oxidative stress. Curr. Top. Med. Chem. 2001; 1:569-590.

31. McDougall GJ, Dobson P, Smith P, Blake A, Stewart D. Assessing potential bioavailability of rapsberry anthocyanins using an in vitro digestion system. J. Agric. Food Chem. 2005; 53:5896-5904.

32. Gorelik S, Lapidot T, Shaham I, Granit R, Ligumsky M, Kohen R, et al. Lipid peroxidation and coupled vitamin oxidation in simulated and human gastric fluid inhibited by dietary polyphenols: Health implications. J. Agric. Food Chem. 2005; 53:3397-3402.

33. Paganga G, RiceEvans CA. The identification of flavonoids as glycosides in human plasma. FEBS Lett. 1997; 401:78-82.
34. Basu TK, Temple, N.J., Garg, M.L. Antioxidants in human health and disease. Wallingford, UK: CABI Publishing; 1999.

35. Scalbert A, Williamson G. Dietary intake and bioavailability of polyphenols. J. Nutr. 2000; 130:2073S-2085S.

36. Hollman PCH, Devries JHM, Vanleeuwen SD, Mengelers MJB, Katan MB. Absorption of dietary quercetin glycosides and quercetin in healthy ileostomy volunteers. Am. J. Clin. Nutr. 1995; 62:1276-1282.

37. Wolffram S, Block M, Ader P. Quercetin-3-glucoside is transported by the glucose carrier SGLT1 across the brush border membrane of rat small intestine. J. Nutr. 2002; 132:630-635.

38. Walgren RA, Karnaky KJ, Lindenmayer GE, Walle T. Efflux of dietary flavonoid quercetin 4 '-beta-glucoside across human intestinal Caco- 2 cell monolayers by apical multidrug resistance-associated protein-2. J. Pharmacol. Exp. Ther. 2000; 294:830-836.

39. Walle T, Otake Y, Walle UK, Wilson FA. Quercetin glucosides are completely hydrolyzed in ileostomy patients before absorption. J. Nutr. 2000; 130:2658-2661.

40. Day AJ, DuPont MS, Ridley S, Rhodes M, Rhodes MJC, Morgan MRA, et al. Deglycosylation of flavonoid and isoflavonoid glycosides by human small intestine and liver beta-glucosidase activity. FEBS Lett. 1998; 436:71-75.

41. Day AJ, Canada FJ, Diaz JC, Kroon PA, Mclauchlan R, Faulds CB, et al. Dietary flavonoid and isoflavone glycosides are hydrolysed by the lactase site of lactase phlorizin hydrolase. FEBS Lett. 2000; 468:166-170.

42. Chalas J, Claise C, Edeas M, Messaoudi C, Vergnes L, Abella A, et al. Effect of ethyl esterification of phenolic acids on low-density lipoprotein oxidation. Biomed. \& Pharmacother. 2001; 55:54-60.

43. Clifford MN. Chlorogenic acids and other cinnamates - nature, occurrence and dietary burden. J. Sci. Food Agric. 1999; 79:362372.

44. Pietta PG. Flavonoids as antioxidants. J. Nat. Prod. 2000; 63:10351042.

45. Zadernowski R, Naczk M, Nesterowicz J. Phenolic acid profiles in some small berries. J. Agric. Food Chem. 2005; 53:2118-2124.

46. Chaovanalikit A, Thompson MM, Wrolstad RE. Characterization and quantification of anthocyanins and polyphenolics in blue honeysuckle (Lonicera caerulea L.). J. Agric. Food Chem. 2004; 52:848-852.

47. Plumb GW, Garcia-Conesa MT, Kroon PA, Rhodes M, Ridley S, Williamson G. Metabolism of chlorogenic acid by human plasma, liver, intestine and gut microflora. J. Sci. Food Agric. 1999; 79:390392.

48. Kroon PA, Williamson G. Hydroxycinnamates in plants and food: current and future perspectives. J. Sci. Food Agric. 1999; 79:355361.

49. Olthof MR, Hollman PCH, Katan MB. Chlorogenic acid and caffeic acid are absorbed in humans. J. Nutr. 2001; 131:66-71.

50. Peppercorn MA, Goldman P. Caffeic acid metabolism by bacteria of human gastrointestinal tract. J. Bacteriol 1971; 108:996-1000.

51. Gonthier MP, Verny MA, Besson C, Remesy C, Scalbert A. Chlorogenic acid bioavailability largely depends on its metabolism by the gut microflora in rats. J. Nutr. 2003; 133:1853-1859.

52. Adam A, Crespy V, Levrat-Verny MA, Leenhardt F, Leuillet M, Demigne $\mathrm{C}$, et al. The bioavailability of ferulic acid is governed primarily by the food matrix rather than its metabolism in intestine and liver in rats. J. Nutr. 2002; 132:1962-1968.

53. Chesson A, Provan GJ, Russell WR, Scobbie L, Richardson AJ, Stewart C. Hydroxycinnamic acids in the digestive tract of livestock and humans. J. Sci. Food Agric. 1999; 79:373-378.

54. Andreasen MF, Kroon PA, Williamson G, Garcia-Conesa MT. Intestinal release and uptake of phenolic antioxidant diferulic acids. Free Radic. Biol. Med. 2001; 31:304-314.

55. Ferguson LR, Zhu ST, Harris PJ. Antioxidant and antigenotoxic effects of plant cell wall hydroxycinnamic acids in cultured HT-29 cells. Mol. Nutr. \& Food Res. 2005; 49:585-593.

56. Kikugawa K, Hakamada T, Hasunuma M, Kurechi T. Reaction of para-hydroxycinnamic acid-derivatives with nitrite and its relevance to nitrosamine formation. J. Agric. Food Chem. 1983; 31:780785 . 
57. RiceEvans CA, Miller NJ, Paganga G. Structure-antioxidant activity relationships of flavonoids and phenolic acids. Free Rad. Biol. Med. 1996; 20:933-956.

58. Vaidyanathan JB, Walle T. Cellular uptake and efflux of the tea flavonoid (-)-epicatechin-3-gallate in the human intestinal cell line Caco-2. J. Pharmacol. Exp. Ther. 2003; 307:745-752.

59. Tsyrlov IB, Mikhailenko VM, Gelboin HV. Isozyme-specific and species-specific susceptibility of cDNA-expressed CYP1A P-450s to different flavonoids. BBA - Prot. Struct. Mol. Enzymol. 1994; 1205:325-335

60. Otake Y, Hsieh F, Walle T. Glucuronidation versus oxidation of the flavonoid galangin by human liver microsomes and hepatocytes. Drug Metabol. Dispos. 2002; 30:576-581.

61. Boutin JA, Meunier F, Lambert PH, Hennig P, Bertin D, Serkiz B et al. In-vivo and in-vitro glucuronidation of the flavonoid diosmetin in rats. DMD 1993; 21:1157-1166.

62. Vaidyanathan JB, Walle T. Glucuronidation and sulfation of the tea flavonoid (-)-epicatechin by the human and rat enzymes. Drug Metabol. Dispos. 2002; 30:897-903.

63. Zhu BT, Ezell EL, Liehr JG. Catechol-O-methyltransferase-catalyzed rapid O-methylation of mutagenic flavonoids - Metabolic inactivation as a possible reason for their lack of carcinogenicity in vivo. J. Biol. Chem. 1994; 269:292-299.

64. Rechner AR, Kuhnle G, Bremner P, Hubbard GP, Moore KP, RiceEvans CA. The metabolic fate of dietary polyphenols in humans. Free Rad. Biol. Med. 2002; 33:220-235.

65. Walle T, Walle UK, Halushka PV. Carbon dioxide is the major metabolite of quercetin in humans. J. Nutr. 2001; 131:2648-2652.

66. Galati G, Moridani MY, Chan TS, O’Brien PJ. Peroxidative metabolism of apigenin and naringenin versus luteolin and quercetin: Glutathione oxidation and conjugation. Free Rad. Bio. Med. 2001 30:370-382

67. Walle T, Vincent TS, Walle UK. Evidence of covalent binding of the dietary flavonoid quercetin to DNA and protein in human intestinal and hepatic cells. Biochem. Pharmacol. 2003; 65:1603-1610.

68. Harris DM, Besselink E, Henning SM, Go VLW, Heber D. Phytoestrogens induce differential estrogen receptor alpha- or betamediated responses in transfected breast cancer cells. Exp. Biol. Med. 2005; 230:558-568.

69. Sesink ALA, O’Leary KA, Hollman PCH. Quercetin gluouronides but not glucosides are present in human plasma after consumption of quercetin-3-glucoside or quercetin-4'-glucoside. J. Nutr. 2001; 131:1938-1941.

70. Bourne LC, Rice-Evans CA. Urinary detection of hydroxycinnamates and flavonoids in humans after high dietary intake of fruit Free Rad. Res. 1998; 28:429-438.

71. Olthof MR, Hollman PCH, Vree TB, Katan MB. Bioavailabilities of quercetin-3-glucoside and quercetin-4 '-glucoside do not differ in humans. J. Nutr. 2000; 130:1200-1203.

72. Ferry DR, Smith A, Malkhandi J, Fyfe DW, deTakats PG, Anderson D, et al. Phase I clinical trial of the flavonoid quercetin Pharmacokinetics and evidence for in vivo tyrosine kinase inhibition. Clin. Cancer Res. 1996; 2:659-668.

73. Ueno I, Nakano N, Hirono I. Metabolic-fate of [C-14] quercetin in the Acl rat. Jpn. J. Exp. Med. 1983; 53:41-50.

74. Fang J, Xia C, Cao ZX, Zheng JZ, Reed E, Jiang BH. Apigenin inhibits VEGF and HIF-1 expression via P13K/AKT/p70S6K1 and HDM2/p53 pathways. FASEB J. 2005; 19:342-353.

75. Schroeter H, Heiss C, Balzer J, Kleinbongard P, Keen CL, Hollenberg NK, et al. (-)-Epicatechin mediates beneficial effects of flavanol-rich cocoa on vascular function in humans. PNAS 2006; 103:1024-1029.

76. Katiyar S, Elmets CA, Katiyar SK. Green tea and skin cancer: photoimmunology, angiogenesis and DNA repair. J. Nutr. Biochem. 2007; 18:287-296

77. Manach C, Texier O, Morand C, Crespy V, Regerat F, Demigne C, et al. Comparison of the bioavailability of quercetin and catechin in rats. Free Rad. Biol. Med. 1999; 27:1259-1266.

78. Clifford MN. Anthocyanins - nature, occurrence and dietary burden. J. Sci. Food Agric. 2000; 80:1063-1072.

79. Kowalczyk E, Krzesinski P, Kura M, Szmigiel B, Blaszczyk J. Anthocyanins in medicine. Pol. J. Pharmacol. 2003; 55:699-702.
80. Lea AGH. HPLC in Food Analysis. London: Academic Press; 1988.

81. McGhie TK, Walton MC. The bioavailability and absorption of anthocyanins: towards a better understanding. Mol Nutr Food Res 2007; 51:702-13.

82. Cao GH, Muccitelli HU, Sanchez-Moreno C, Prior RL. Anthocyanins are absorbed in glycated forms in elderly women: a pharmacokinetic study. AJCN 2001; 73:920-926.

83. Wu XL, Cao GH, Prior RL. Absorption and metabolism of anthocyanins in elderly women after consumption of elderberry or blueberry. J. Nutr. 2002; 132:1865-1871.

84. Perez-Vicente A, Gil-Izquierdo A, Garcia-Viguera C. In vitro gastrointestinal digestion study of pomegranate juice phenolic compounds, anthocyanins, and vitamin C. J. Agric. Food Chem. 2002; 50:2308-2312.

85. Milbury PE, Cao GH, Prior RL, Blumberg J. Bioavailablility of elderberry anthocyanins. Mech. Ageing Dev. 2002; 123:997-1006.

86. Howell AB. Cranberry proanthocyanidins and the maintenance of urinary tract health. Crit. Rev. Food Sci. Nutr. 2002; 42:273-278.

87. Ali BH, Mousa HM, El-Mougy S. The effect of a water extract and anthocyanins of Hibiscus sabdariffa L. on paracetamol-induced hepatoxicity in rats. Phytother. Res. 2003; 17:56-59.

88. Rechner AR, Kuhnle G, Hu HL, Roedig-Penman A, van den Braak $\mathrm{MH}$, Moore KP, et al. The metabolism of dietary polyphenols and the relevance to circulating levels of conjugated metabolites. Free Rad. Res. 2002; 36:1229-1241.

89. Seeram NP, Nair MG. Inhibition of lipid peroxidation and structure-activity-related studies of the dietary constituents anthocyanins, anthocyanidins, and catechins. J. Agric. Food Chem. 2002; 50:5308-5312.

90. Valentova K, Stejskal D, Bednar P, Vostalova J, Cihalik C, Vecerova $\mathrm{R}$, et al. Biosafety, antioxidant status, and metabolites in urine after consumption of dried cranberry juice in healthy women: A pilot double-blind placebo-controlled trial. J. Agric. Food Chem. 2007; 55:3217-3224.

91. Amico V, Napoli EM, Renda A, Ruberto G, Spatafora C, Tringali C. Constituents of grape pomace from the Sicilian cultivar 'Nerello Mascalese'. Food Chem. 2004; 88:599-607.

92. Macheix J, Fleuriet, A., Billot, J. Fruit phenolics. Boca Raton: CRC Press; 1990.

93. Wang H, Cao GH, Prior RL. Oxygen radical absorbing capacity of anthocyanins. J. Agric. Food Chem. 1997; 45:304-309.

94. Matsui T, Ueda T, Oki T, Sugita K, Terahara N, Matsumoto K. Alpha-glucosidase inhibitory action of natural acylated anthocyanins. 1. Survey of natural pigments with potent inhibitory activity. J. Agric. Food Chem. 2001; 49:1948-1951.

95. Umoren J, Kies C. Commercial soybean starch blocker consumption - Impact on weight-gain and on copper, lead and zinc status of rats. Plant Food. Hum. Nutr. 1992; 42:135-142.

96. Block TM, Lu XY, Platt FM, Foster GR, Gerlich WH, Blumberg BS, et al. Secretion of human hepatitis-B virus is inhibited by the imino sugar N-butyldeoxynojirimycin. PNAS 1994; 91:2235-2239.

97. Martin S, Giannone G, Andriantsitohaina R, Martinez MC. Delphinidin, an active compound of red wine, inhibits endothelial cell apoptosis via nitric oxide pathway and regulation of calcium homeostasis. Br. J. Pharmacol. 2003; 139:1095-1102.

98. Hamdy MK, Pratt DE, Powers JJ, Somaatmadja D. Anthocyanins. 3. Disc sensitivity assay of Inhibition of bacterial growth by pelargonidin 3-monoglucoside and its degradation products. J. Food Sci. 1961; 26:457-\&.

99. Kwon JY, Lee KW, Hur HJ, Lee HJ. Peonidin inhibits phorbol-ester-induced COX-2 expression and transformation in JB6 P+ cells by blocking phosphorylation of ERK-1 and -2. Sig. Transduction Pathways, Pt C 2007; 1095:513-520.

100. Neto CC, Krueger CG, Lamoureaux TL, Kondo M, Vaisberg AJ, Hurta RAR, et al. MALDI-TOF MS characterization of proanthocyanidins from cranberry fruit (Vaccinium macrocarpon) that inhibit tumor cell growth and matrix metalloproteinase expression in vitro. J. Sci. Food Agric. 2006; 86:18-25.

101. Howell AB. Bioactive compounds in cranberries and their role in prevention of urinary tract infections. Mol Nutr Food Res 2007; $51: 732-7$ 
102. Foo LY, Lu YR, Howell AB, Vorsa N. A-type proanthocyanidin trimers from cranberry that inhibit adherence of uropathogenic P-fimbriated Escherichia coli. J. Nat. Prod. 2000; 63:1225-1228.

103. Ferreira D, Marais JP, Slade D. Phytochemistry of the mopane, Colophospermum mopane. Phytochemistry 2003; 64:31-51.

104. de Colmenares NG, Ramirez-Martinez JR, Aldana JO, RamosNino ME, Clifford MN, Pekerar S, et al. Isolation, characterisation and determination of biological activity of coffee proanthocyanidins. J. Sci. Food Agric. 1998; 77:368-372.

105. Puupponen-Pimia R, Nohynek L, Hartmann-Schmidlin S, Kahkonen M, Heinonen M, Maatta-Riihinen K, et al. Berry phenolics selectively inhibit the growth of intestinal pathogens. J Appl. Microb. 2005; 98:991-1000.

106. Puupponen-Pimia R, Nohynek L, Alakomi HL, Oksman-Caldentey KM. Bioactive berry compounds - novel tools against human pathogens. Appl. Microb. Biotechnol. 2005; 67:8-18.

107. Aviram M, Fuhrman B. Wine flavonoids protect against LDL oxidation and atherosclerosis. Ann. N. Y. Acad. Sci. 2002; 957:146161.

108. Ruel G, Couillard C. Evidences of the cardioprotective potential of fruits: the case of cranberries. Mol Nutr Food Res 2007; 51:692-701.

109. Zafra-Stone S, Yasmin T, Bagchi M, Chatterjee A, Vinson JA, Bagchi D. Berry anthocyanins as novel antioxidants in human health and disease prevention. Mol Nutr Food Res 2007; 51:67583.

110. Heinonen M. Antioxidant activity and antimicrobial effect of berry phenolics-a Finnish perspective. Mol Nutr Food Res 2007; 51:684-91.

111. Kim YC, Chung, S.K. Reactive oxygen radical species scavenging effects of Korean medicinal plant leaves. Food Sci. Biotechnol. 2002; 11:407-411.

112. Neto CC. Cranberry and its phytochemicals: A review of in vitro anticancer studies. J. Nutr. 2007; 137:186S-193S.

113. Reed J. Cranberry flavonoids, atherosclerosis and cardiovascular health. Crit. Rev. Food Sci. Nutr. 2002; 42:301-316.

114. Tsuda T, Horio F, Osawa T. Cyanidin 3-O-beta-D-glucoside suppresses nitric oxide production during a zymosan treatment in rats. J. Nutr. Sci. Vitaminology 2002; 48:305-310.

115. Duthie SJ. Berry phytochemicals, genomic stability and cancer: evidence for chemoprotection at several stages in the carcinogenic process. Mol. Nutr. Food Res. 2007; 51:665-74.

116. Duthie SJ, Jenkinson AM, Crozier A, Mullen W, Pirie L, Kyle J, et al. The effects of cranberry juice consumption on antioxidant status and biomarkers relating to heart disease and cancer in healthy human volunteers. Eur. J. Nutr. 2006; 45:113-122.

117. Neto CC. Cranberry and blueberry: evidence for protective effects against cancer and vascular diseases. Mol Nutr Food Res 2007 51: $652-64$

118. Svarcova I, Valentova, K., Ulrichova, J., Simanek, V. Antioxidant activity of phenolic fraction from Lonicera caerulea L. var. kamtschatica berries. XXIV. Xenobiochemicke sympozium. 22.-24.5. 2007; Liptovsky Jan, p. 76

119. Duthie SJ. Berry phytochemicals, genomic stability and cancer: Evidence for chemoprotection at several stages in the carcinogenic process. Mol. Nutr. Food Res. 2007; 51:665-674.

120. Ahn D, Putt D, Kresty L, Stoner GD, Fromm D, Hollenberg PF The effects of dietary ellagic acid on rat hepatic and esophageal mucosal cytochromes P450 and phase II enzymes. Carcinogenesis 1996; 17:821-828.

121. Carlton PS, Kresty LA, Siglin JC, Morse MA, Lu J, Morgan C, et al. Inhibition of N-nitrosomethylbenzylamine-induced tumori- genesis in the rat esophagus by dietary freeze-dried strawberries. Carcinogenesis 2001; 22:441-446.

122. Lee LT, Huang YT, Hwang JJ, Lee PPH, Ke FC, Nair MP, et al. Blockade of the epidermal growth factor receptor tyrosine kinase activity by quercetin and luteolin leads to growth inhibition and apoptosis of pancreatic tumor cells. Anticancer Res. 2002; 22:1615-1627.

123. Choi JA, Kim JY, Lee JY, Kang CM, Kwon HJ, Yoo YD, et al. Induction of cell cycle arrest and apoptosis in human breast cancer cells by quercetin. Int. J. Oncology 2001; 19:837-844.

124. Ranelletti FO, Maggiano N, Serra FG, Ricci R, Larocca LM, Lanza P, et al. Quercetin inhibits p21-ras expression in human colon cancer cell lines and in primary colorectal tumors. Int. J. Cancer 2000; 85:438-445.

125. Morrow DMP, Fitzsimmons PEE, Chopra M, McGlynn H. Dietary supplementation with the anti-tumour promoter quercetin: its effects on matrix metalloproteinase gene regulation. Mutat. Res. Fund. Mol. Mech. Mut. 2001; 480:269-276.

126. Chen PN, Chu SC, Chiou HL, Kuo WH, Chiang CL, Hsieh YS Mulberry anthocyanins, cyanidin 3-rutinoside and cyanidin 3 glucoside, exhibited an inhibitory effect on the migration and invasion of a human lung cancer cell line. Cancer Lett. 2006; 235:248-259.

127. Serraino I, Dugo L, Dugo P, Mondello L, Mazzon E, Dugo G, et al. Protective effects of cyanidin-3-O-glucoside from blackberry extract against peroxynitrite-induced endothelial dysfunction and vascular failure. Life Sci. 2003; 73:1097-1114.

128. Cooke D, Steward WP, Gescher AJ, Marczylo T. Anthocyans from fruits and vegetables - Does bright colour signal cancer chemopreventive activity? Eur. J. Cancer 2005; 41:1931-1940.

129. Schmidt BM, Erdman JW, Lila MA. Differential effects of blueberry proanthocyanidins on androgen sensitive and insensitive human prostate cancer cell lines. Cancer Lett. 2006; 231:240-246.

130. Roy S, Khanna S, Alessio HM, Vider J, Bagchi D, Bagchi M, et al. Anti-angiogenic property of edible berries. Free Rad. Res. 2002; 36:1023-1031.

131. Broadhurst CL, Polansky MM, Anderson RA. Insulin-like biological activity of culinary and medicinal plant aqueous extracts in vitro. J. Agric. Food Chem. 2000; 48:849-852.

132. McDougall GJ, Dobson P, Smith P, Blake A, Stewart D. Assessing potential bioavallability of raspberry anthocyanins using an in vitro digestion system. Journal of Agricultural and Food Chemistry 2005; 53:5896-5904

133. McDougall GJ, Stewart D. The inhibitory effects of berry polyphenols on digestive enzymes. BioFactors 2005; 23:189-195.

134. Jayaprakasam B, Vareed SK, Olson LK, Nair MG. Insulin secretion by bioactive anthocyanins and anthocyanidins present in fruits. J. Agric. Food Chem. 2005; 53:28-31.

135. Yawadio R, Tanimori S, Morita N. Identification of phenolic compounds isolated from pigmented rices and their aldose reductase inhibitory activities. Food Chem. 2007; 101:1616-1625.

136. Adisakwattana S, Ngamrojanavanich N, Kalampakorn K, Tiravanit W, Roengsumran S, Yibchok-Anun S. Inhibitory activity of cyanidin-3-rutinoside on alpha-glucosidase. J. Enzym. Inhib. Med. Chem. 2004; 19:313-316.

137. Camire ME. Billberries and blueberries as functional foods and nutraceuticals. Herbs, Botanicals and Teas. Lancaster: Technomic Publishing Company; 2000.

138. Bickford PC, Gould T, Briederick L, Chadman K, Pollock A, Young D, et al. Antioxidant-rich diets improve cerebellar physiology and motor learning in aged rats. Brain Res. 2000; 866:211217. 